\title{
Influence of Modified Soil Environment on Growth and Yield of Summer Baby Corn (Zea mays L.) as Affected by Irrigation and Mulch in West Bengal, India
}

\author{
Trisha Manna ${ }^{1}$, G. Saha ${ }^{1}$, M.K. Nanda ${ }^{1}$, D. Dutta ${ }^{2}$ and A. Saha ${ }^{2}$ \\ ${ }^{1}$ Department of Agricultural Meteorology and Physics, ${ }^{2}$ Department of Agronomy, \\ B.C.K.V, Nadia, West Bengal-741252, India \\ *Corresponding author
}

\begin{tabular}{l} 
Ke y w o r d s \\
Baby corn, \\
Irrigation, Mulch, \\
Soil environment, \\
Yield \\
\hline Article Info \\
\hline $\begin{array}{l}\text { Accepted: } \\
\text { 04 December } 2018 \\
\text { Available Online: } \\
\text { 10 January } 2019\end{array}$ \\
\hline
\end{tabular}

\section{A B S T R A C T}

Two years field experiment was conducted during pre-kharif seasons of 2016 and 2017 at Instructional Farm, Jaguli, B.C.K.V, Nadia, W.B, to study the effect of irrigation and mulches on soil environment modification, growth, yield attributes and yield of summer baby corn (Zea mays L.) var. G5414-F1 hybrid. The experiment was designed in split plot with three replications. The treatments comprised of three levels of irrigation (IW: CPE 1.0, 0.8 and 0.6) as main plot and four levels of mulching (no mulch-control, 30 $\mu$ polythene mulch, paddy straw mulch@4 t ha ${ }^{-1}$ and geotextile mulch @ $500 \mathrm{~g} \mathrm{~m}^{-2}$ ) as sub plots. Results revealed that significantly taller plants, maximum number of functional leaves plant ${ }^{-1}$, higher root and shoot length, shoot diameter and yield attributes i.e. length, weight and girth of baby cobs (with and without husk) were obtained by IW: CPE 1.0 and polythene mulch. Significantly higher cob yield $\left(2270 \mathrm{~kg} \mathrm{ha}^{-1}\right)$, corn yield $\left(1795 \mathrm{~kg} \mathrm{ha}^{-1}\right)$ and green fodder yield $\left(37 \mathrm{t} \mathrm{ha}^{-1}\right)$ were recorded from the interaction effect of IW: CPE 1.0 and polythene mulch. Soil temperature at 5, 10 and $20 \mathrm{~cm}$ depth was lower in IW: CPE 1.0 and maximum under IW: CPE 0.6. Mulch with polythene recorded highest soil temperature at harvest compared to no mulch and paddy straw mulch at both the depths (5 and $10 \mathrm{~cm}$ ). Higher soil moisture (\%) was observed at $15-30 \mathrm{~cm}$ depth under IW: CPE 1.0 and polythene mulch during initial growth stages. Strong positive correlation was observed with soil temperature and different growth parameters, yield attributes and yield of summer baby corn.

\section{Introduction}

Maize (Zea mays L.), one of the most versatile crop with wider adaptability is the third most important cereal crop in the world next after wheat and rice in terms of area and first in terms of productivity. Green cobs harvested 23 days of silk emergence but prior to fertilization are known as baby corn (Pandey et al., 2000). Being a $\mathrm{C}_{4}$ plant, baby corn has higher photosynthetic efficiency and higher yield potential, that's why it is called "queen of cereals" or "miracle crop". Out of $160 \mathrm{~m}$ ha of cultivated land, $39 \mathrm{~m}$ ha is irrigated by ground water, $22 \mathrm{~m}$ ha by irrigation canals and rest two third area still depends on monsoon 
rainfall in India. With $1544 \mathrm{~m}^{3}$ per capita water availability, India is continuously moving towards water stressed country (Dhawan, 2017). In this context, judicial application of water at proper time and with proper amount and also to conserve the soil moisture for longer time is of prime importance. So in our study, scheduling of irrigation with the concept of depth of irrigation water (IW) and cumulative pan evaporation (CPE) and applying different types of mulch, we tried to understand how the treatments affect the soil environment and different growth, yield parameters and finally yield of pre-kharif baby corn in Gangetic West Bengal.

\section{Materials and Methods}

\section{Study site}

Field experiments were conducted during prekharif/ summer seasons of 2016 and 2017 at Instructional Farm, Jaguli, Bidhan Chandra Krishi Viswavidyalaya, Mohanpur, Nadia,

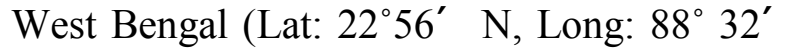
E, Alt: $9.75 \mathrm{~m}$ above mean sea level).

The site is under new alluvial zone, with sandy clay loam soil and neutral soil $\mathrm{pH}$. Meteorological data during experimental period showed that the crop received 145.22 $\mathrm{mm}$ and $40.46 \mathrm{~mm}$ of total rainfall during 2016 and 2017. The weekly pan evaporation value ranged from 16.8 to $42.9 \mathrm{~mm} \mathrm{day}^{-1}$ and 18.6 to $37.6 \mathrm{~mm} \mathrm{day}^{-1}$ in two years respectively.

\section{Experimental set up}

The experiment was laid out in split plot design with irrigation and mulching as main plot and sub-plot factors. Three levels of irrigation ( IW: CPE 1.0, 0.8 and 0.6 as $\mathrm{I}_{1}, \mathrm{I}_{2}$ and $\mathrm{I}_{3}$ respectively) and four levels of mulching (no mulch or control, $30 \mu$ blue polythene mulch, paddy straw mulch@4t $\mathrm{ha}^{-1}$, geotextile mulch @ $500 \mathrm{~g} \mathrm{~m}^{-2}$ as $\mathrm{M}_{0}, \mathrm{M}_{1}$, $\mathrm{M}_{2}$ and $\mathrm{M}_{3}$ respectively) thus 12 treatment combinations, replicated thrice with total 36 plots. Variety G5414- $\mathrm{F}_{1}$ hybrid was sown in raised bed with $40 \mathrm{~cm} \times 20 \mathrm{~cm}$ spacing, seed rate $20 \mathrm{~kg} \mathrm{ha}^{-1}$. Date of sowing was 19th February both the years. Depth of irrigation was maintained at $5 \mathrm{~cm}$, first common irrigation was applied at the time of sowing, then according to treatments as surface irrigation in the channels. Manure, fertilizer was applied as conventional practice.

\section{Data collection}

Periodical soil moisture content (\%) data at 0 15 and $15-30 \mathrm{~cm}$ depth was collected at 20, 40 and 60 DAS by gravimetric method using the following formula by Black (1965).

\section{Soil moisture content( $(\%)$ \\ $=\frac{\text { wet weight of soil sample }(g)-\text { dry weight of soil sample }(g)}{\text { dry weight of soil sample }(g)}$ \\ $\times 100$}

Soil temperature was measured with soil thermometer inserted in three channels at 5, 10 and $20 \mathrm{~cm}$ depths at an angle of $45^{\circ}$, kept for 5 minutes to record temperature between 1130 hrs to $1200 \mathrm{hrs}$. All growth parameters were recorded freshly from 20 to 60 DAS whereas yield attributes and yield data were collected at the time of harvest (60 DAS). Except soil moisture (\%), all meteorological and plant data were pooled over two years.

\section{Statistical analysis}

Data on various aspects were subjected to statistical analysis by analysis of variance (ANOVA) suggested by Gomez and Gomez (1984), the significance of difference for treatments were tested by "F" test at 5\% level. Association of various data was done by Pearson's correlation. 


\section{Results and Discussion}

Influence of irrigation and mulch on soil moisture

The data pertaining to soil moisture content (\%) of baby corn as influenced by irrigation and mulching in $0-15 \mathrm{~cm}$ and $15-30 \mathrm{~cm}$ soil depths at different intervals during 2016 and 2017 are presented in Table: 1. Both the treatments significantly influenced the soil moisture percentage in both the years.

Significantly higher soil moisture $(26.85 \%)$ was observed at 20 DAS (15-30 cm depth) under IW: CPE $1.0\left(\mathrm{I}_{1}\right)$ and lower moisture content $(18.46 \%)$ was recorded at 60 DAS (harvest) from the same soil layer in IW: CPE $0.6\left(\mathrm{I}_{3}\right)$. On an average soil moisture found higher at $15-30 \mathrm{~cm}$ depth at 20 DAS and minimum at 60 DAS (harvest). Variation of soil moisture (\%) was higher at 20 DAS at 15$30 \mathrm{~cm}$ depth in 2016.

Higher extractable soil moisture $(26.91 \%)$ was found in polythene mulch $\left(\mathrm{M}_{1}\right)$ from $15-30 \mathrm{~cm}$ depth at 20 DAS, and level of soil moisture was lower (16.71\%) at 60 DAS (harvest) from same layer under no mulch $\left(\mathrm{M}_{0}\right)$ situation. At 40 DAS the effect of polythene mulch $\left(\mathrm{M}_{1}\right)$, paddy straw mulch $\left(\mathrm{M}_{2}\right)$ and geotextile mulch $\left(\mathrm{M}_{3}\right)$ over soil moisture individually at two different depths was statistically at par, compared to significant lower moisture content under control plots $\left(\mathrm{M}_{0}\right)$. Significant difference of soil moisture percentage was higher at 20 DAS and minimum variation was at 40 DAS in 2016.

Statistically significant interaction effect between treatments $(\mathrm{I} \times \mathrm{M})$ was registered except 15-30 cm depth at 40 DAS in 2016.

In 2017 similar results were observed but maximum soil moisture $(23.89 \%)$ reduced from previous year 20 DAS in IW: CPE 1.0
$\left(\mathrm{I}_{1}\right)$ and minimum soil moisture (19.80\%) content increased from previous year in IW: CPE $0.6 \quad\left(\mathrm{I}_{3}\right)$ both at $15-30 \mathrm{~cm}$ depth. Maximum soil moisture variation was recorded at 60 DAS (harvest).

In 2017 also polythene mulch $\left(\mathrm{M}_{1}\right)$ recorded maximum soil moisture $(25.54 \%)$ at 20 DAS from $15-30 \mathrm{~cm}$ soil layer (decreased from 2016) and minimum amount of moisture $(17.85 \%)$ from no mulch $\left(\mathrm{M}_{0}\right)$ plots (increased from 2016). Maximum variation of soil moisture was recorded at 60 DAS (harvest).

Significant difference in soil moisture due to treatment interaction effect $(\mathrm{I} \times \mathrm{M})$ was recorded except $0-15 \mathrm{~cm}$ soil depth at 60 DAS (harvest).

\section{Influence of irrigation and mulch on soil temperature}

Soil temperature as observed from 20 to 60 DAS at an interval of 10 days (pooled of 2016 and 2017) at 5, 10 and $20 \mathrm{~cm}$ depths under different treatments are illustrated in Figure 1. It is clear from the graphs, that the sequence of soil temperature $\left({ }^{\circ} \mathrm{C}\right)$ under different irrigation treatments was IW: CPE $0.6\left(\mathrm{I}_{3}\right)>\mathrm{IW}$ : $\mathrm{CPE}$ $0.8\left(\mathrm{I}_{2}\right)>\mathrm{IW}$ : CPE 1.0( $\left.\mathrm{I}_{1}\right)$. For $\mathrm{I}_{3}$, soil temperature at $5 \mathrm{~cm}$ depth ranged from $32.33^{\circ} \mathrm{C}$ to $36.37^{\circ} \mathrm{C}$. At $5 \mathrm{~cm}$ depth soil temperature of $\mathrm{I}_{2}$ ranged from $30.12^{\circ} \mathrm{C}$ to $32.99^{\circ} \mathrm{C}$ and for $\mathrm{I}_{1}$ soil temperature value ranged from $28.42^{\circ} \mathrm{C}$ to $32.82^{\circ} \mathrm{C}$. For $10 \mathrm{~cm}$ soil depth, temperature ranged from $30.64^{\circ} \mathrm{C}$ to $33.36^{\circ} \mathrm{C}$ in $\mathrm{I}_{3}, 29.12^{\circ} \mathrm{C}$ to $32.97^{\circ} \mathrm{C}$ in $\mathrm{I}_{2}$ and $28.00^{\circ} \mathrm{C}$ to $32.73^{\circ} \mathrm{C}$ in $\mathrm{I}_{1}$. For $20 \mathrm{~cm}$ soil depth, soil temperature ranged from $31.96^{\circ} \mathrm{C}$ to $33.11^{\circ} \mathrm{C}$ in $\mathrm{I}_{3}, 31.35^{\circ} \mathrm{C}$ to $32.80^{\circ} \mathrm{C}$ in $\mathrm{I}_{2}$ and $26.86^{\circ} \mathrm{C}$ to $32.79^{\circ} \mathrm{C}$ in $\mathrm{I}_{1}$. Maximum variation in $5 \mathrm{~cm}$ soil temperature was recorded at 30 DAS, minimum variation at 60 DAS. Variation of soil temperature at $10 \mathrm{~cm}$ was higher at 30 DAS and lowest variation was observed at 60 DAS. Similarly soil 
temperature at $20 \mathrm{~cm}$ depth varied maximum at 30 DAS and lowest variation was at 50 DAS.

For mulching, the soil temperature recorded at $20,30,40,50$ and 60 DAS at $5 \mathrm{~cm}, 10 \mathrm{~cm}$ and $20 \mathrm{~cm}$ depths showed temperature sequence at polythene mulch $\left(\mathrm{M}_{1}\right)>$ geotextile mulch $\left(\mathrm{M}_{3}\right)>$ paddy straw mulch $\left(\mathrm{M}_{2}\right)>$ no mulch $\left(\mathrm{M}_{0}\right)$. Soil temperature at $5 \mathrm{~cm}$ depth varied from $31.96^{\circ} \mathrm{C}$ to $34.28^{\circ} \mathrm{C}$ in $\mathrm{M}_{1}, 30.75^{\circ} \mathrm{C}$ to $32.89^{\circ} \mathrm{C}$ in $\mathrm{M}_{3}, 30.67^{\circ} \mathrm{C}$ to $32.77^{\circ} \mathrm{C}$ in $\mathrm{M}_{2}$, and $29.46^{\circ} \mathrm{C}$ to $32.30^{\circ} \mathrm{C}$ in no mulch plots. Soil temperature at $10 \mathrm{~cm}$ depth ranged from $30.40^{\circ} \mathrm{C}$ to $33.82^{\circ} \mathrm{C}$ for $\mathrm{M}_{1}, 29.49^{\circ} \mathrm{C}$ to $33.19^{\circ} \mathrm{C}$ in $\mathrm{M}_{3}, 29.06^{\circ} \mathrm{C}$ to $32.96{ }^{\circ} \mathrm{C}$ in $\mathrm{M}_{2}$, and $28.69^{\circ} \mathrm{C}$ to $32.32^{\circ} \mathrm{C}$ in no mulch. Soil temperature measured at $20 \mathrm{~cm}$ ranged from $31.94^{\circ} \mathrm{C}$ to $34.03^{\circ} \mathrm{C}$ in $\mathrm{M}_{1}, 30.19^{\circ} \mathrm{C}$ to $32.98^{\circ} \mathrm{C}$ in $\mathrm{M}_{3}, 29.45^{\circ} \mathrm{C}$ to $32.65^{\circ} \mathrm{C}$ in $\mathrm{M}_{2}$, and $28.66^{\circ} \mathrm{C}$ to $32.55^{\circ} \mathrm{C}$ in no mulch treatment. For $5 \mathrm{~cm}$ soil depth, temperature variation was more at 30 DAS; minimum variation was at 50 DAS. For $10 \mathrm{~cm}$ soil depth, maximum temperature variation was recorded at 40 DAS, minimum variation at $50 \mathrm{DAS}$. For $20 \mathrm{~cm}$ depth, maximum soil temperature variation was recorded at 30 DAS and minimum temperature variation was observed at 50 DAS. Soil temperature at 5, 10 and $20 \mathrm{~cm}$ depth was lower in IW: CPE 1.0 and maximum under IW: CPE 0.6.

This may be due to higher number of functional leaves per plant, higher LAI, there was sufficient transpiration from plants and more soil evaporation, combindly increasing latent heat loss from the soil resulted by lower soil temperature. The highest soil temperature at above mentioned depths was recorded in mulch with polythene over rest of the treatments. Mulch with polythene recorded highest soil temperature at harvest compared to no mulch and paddy straw mulch at the both the depths $(5$ and $10 \mathrm{~cm})$. Similar results were also reported by Muragan et al., 2003.
Influence of irrigation and mulch on growth parameters

Tallest plants were observed at 60 DAS under both the treatments. Irrigation scheduled at IW: CPE $1.0 \quad\left(\mathrm{I}_{1}\right)$ recorded taller plants compared to IW: CPE $0.8\left(\mathrm{I}_{2}\right)$ and IW: CPE $0.6\left(\mathrm{I}_{3}\right)$. During harvest (60 DAS), $\mathrm{I}_{1}$ recorded tallest plant height of $174.0 \mathrm{~cm}$. Soil moisture always remain at field capacity in IW: CPE 1.0 , because of which plant absorb more moisture and nutrients from soil which reflected in increase in cell elongation and multiplication. These results are conformity by those reported by Hussaini et al., 2001. Polythene mulch $\left(\mathrm{M}_{1}\right)$ recorded taller plants compared to geotextile mulch $\left(\mathrm{M}_{3}\right)$ and paddy straw mulch $\left(\mathrm{M}_{2}\right)$ during all growth stages. Tallest plants were observed at 60 DAS (171.6 $\mathrm{cm})$ by polythene mulch $\left(\mathrm{M}_{1}\right)$, followed by geotextile mulch $\left(\mathrm{M}_{3}\right)(168.7 \mathrm{~cm})$ and paddy straw mulch $\left(\mathrm{M}_{2}\right)(162.7 \mathrm{~cm})$ and lowest plant height was observed in control $\left(\mathrm{M}_{0}\right)$ plots $(160.3 \mathrm{~cm})$. The results are conformity with findings of Uwah and Iwo (2011). Interaction effect $(\mathrm{I} \times \mathrm{M})$ was also significant at all stages.

Maximum functional leaf number (13.9) was recorded at 60 DAS by IW: CPE $1.0\left(\mathrm{I}_{1}\right)$ and lowest leaf number (11.8) was observed by IW: $\mathrm{CPE} 0.6\left(\mathrm{I}_{3}\right)$. Maximum number of functional leaves (14.5) was recorded in plots treated with polythene mulch $\left(\mathrm{M}_{1}\right)$, followed by geotextile mulch (13.0) and paddy straw mulch (12.5). Lowest number of functional leaves (11.2) was observed in control plots. Treatment interaction (I $\times \mathrm{M})$ was statistically significant at 30, 40 and 60 DAS.

Root length found maximum by IW: CPE 1.0 $(31.08 \mathrm{~cm})$ and with application of polythene mulch $(28.83 \mathrm{~cm})$ at 60 DAS. Maximum shoot length was recorded by IW: CPE 1.0 (93.90 $\mathrm{cm})$ and polythene mulch $(98.61 \mathrm{~cm})$ at 60 DAS. Shoot girth reached at maximum value at 60 DAS. 
Table.1 Influence of irrigation and mulch on soil moisture (\%) at different depths in 2016 and 2017

\begin{tabular}{|c|c|c|c|c|c|c|c|c|c|c|c|c|c|}
\hline & & \multicolumn{6}{|c|}{2016} & \multicolumn{6}{|c|}{2017} \\
\hline & & \multicolumn{2}{|c|}{20 DAS } & \multicolumn{2}{|c|}{40 DAS } & \multicolumn{2}{|c|}{$\begin{array}{c}60 \text { DAS } \\
\text { (Harvest) }\end{array}$} & \multicolumn{2}{|c|}{20 DAS } & \multicolumn{2}{|c|}{40 DAS } & \multicolumn{2}{|c|}{$\begin{array}{c}\text { 60 DAS } \\
\text { (Harvest) }\end{array}$} \\
\hline \multicolumn{2}{|c|}{ Soil depth (cm) } & $0-15$ & $15-30$ & $0-15$ & $15-30$ & $0-15$ & $15-30$ & $0-15$ & $15-30$ & $0-15$ & $15-30$ & $0-15$ & $15-30$ \\
\hline \multicolumn{14}{|c|}{ Treatments } \\
\hline \multicolumn{2}{|c|}{$I_{1}(\mathrm{IW}: C P E=1.0)$} & 24.92 & 26.85 & 22.17 & 21.63 & 23.60 & 19.92 & 23.41 & 23.89 & 22.93 & 23.63 & 22.77 & 21.88 \\
\hline \multicolumn{2}{|c|}{$\mathrm{I}_{2}(\mathrm{IW}: \mathrm{CPE}=0.8)$} & 24.48 & 26.42 & 21.01 & 20.90 & 21.85 & 19.19 & 23.19 & 23.61 & 21.78 & 23.25 & 21.70 & 20.56 \\
\hline \multicolumn{2}{|c|}{$\mathrm{I}_{3}(\mathrm{IW}: \mathrm{CPE}=0.6)$} & 21.73 & 25.62 & 20.79 & 20.56 & 21.54 & 18.46 & 22.98 & 22.82 & 21.61 & 22.24 & 21.02 & 19.80 \\
\hline \multicolumn{2}{|c|}{ SEm $( \pm)$} & 0.17 & 0.18 & 0.09 & 0.17 & 0.11 & 0.09 & 0.08 & 0.04 & 0.11 & 0.08 & 0.12 & 0.28 \\
\hline \multicolumn{2}{|c|}{ CD (at 5\%) } & 0.68 & 0.71 & 0.36 & 0.67 & 0.45 & 0.37 & 0.30 & 0.14 & 0.42 & 0.33 & 0.47 & 1.10 \\
\hline \multicolumn{2}{|c|}{$\mathrm{M}_{0}($ Control $)$} & 21.19 & 24.90 & 19.97 & 20.03 & 21.16 & 16.71 & 21.17 & 21.68 & 20.23 & 21.17 & 19.78 & 17.85 \\
\hline \multicolumn{2}{|c|}{$\mathbf{M}_{1}($ Polythene mulch) } & 25.19 & 26.91 & 22.50 & 21.45 & 24.05 & 20.80 & 25.23 & 25.54 & 24.31 & 25.18 & 24.26 & 23.19 \\
\hline \multicolumn{2}{|c|}{$\begin{array}{c}M_{2}(\text { Paddy straw } \\
\text { mulch })\end{array}$} & 24.57 & 26.67 & 21.58 & 21.85 & 22.18 & 17.86 & 21.87 & 22.04 & 20.91 & 23.98 & 20.36 & 19.66 \\
\hline \multicolumn{2}{|c|}{$\mathbf{M}_{3}$ (Geotextile mulch) } & 23.89 & 26.71 & 21.24 & 20.80 & 21.93 & 21.38 & 24.50 & 24.51 & 22.97 & 21.82 & 22.93 & 22.29 \\
\hline \multicolumn{2}{|c|}{ SEm $( \pm)$} & 0.15 & 0.94 & 0.12 & 0.20 & 0.26 & 0.11 & 0.16 & 0.11 & 0.18 & 0.12 & 0.32 & 0.17 \\
\hline \multicolumn{2}{|c|}{ CD (at 5\%) } & 0.44 & 2.74 & 0.35 & 0.59 & 0.76 & 0.34 & 0.48 & 0.34 & 0.52 & 0.35 & 0.94 & 0.52 \\
\hline \multirow[t]{2}{*}{$\mathbf{I} \times \mathbf{M}$} & $\operatorname{SEm}( \pm)$ & 0.26 & 0.24 & 0.21 & 0.34 & 0.45 & 0.20 & 0.28 & 0.20 & 0.31 & 0.20 & 0.55 & 0.30 \\
\hline & CD (at 5\%) & 0.76 & 0.70 & 0.61 & NS & 1.32 & 0.58 & 0.83 & 0.59 & 0.91 & 0.61 & NS & 0.89 \\
\hline
\end{tabular}


Table.2 Plant height $(\mathrm{cm})$, number of functional leaves plant ${ }^{-1}$, root length $(\mathrm{cm})$, shoot length $(\mathrm{cm})$, shoot girth $(\mathrm{cm})$ affected by irrigation and mulch (pooled of 2016 and 2017)

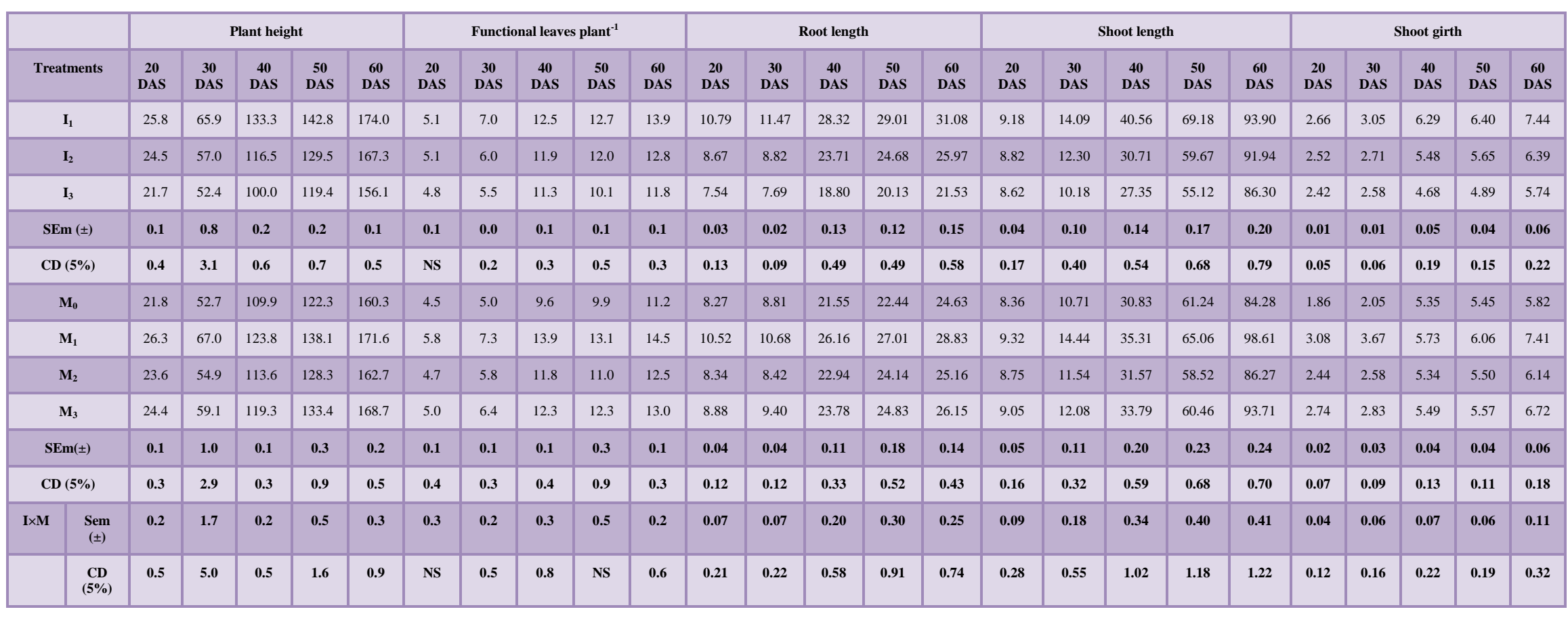


Table.3 Cob yield, corn yield and green fodder yield of baby corn influenced by irrigation and mulch

\begin{tabular}{|c|c|c|c|c|}
\hline \multicolumn{2}{|r|}{ Treatments } & $\begin{array}{c}\text { Cob yield } \\
\left(\mathrm{kg} \mathrm{ha}^{-1}\right)\end{array}$ & $\begin{array}{l}\text { Corn yield } \\
\left(\mathrm{kg} \mathrm{ha}^{-1}\right)\end{array}$ & $\begin{array}{c}\text { Green fodder yield } \\
\left(\mathrm{t} \mathrm{ha}^{-1}\right)\end{array}$ \\
\hline \multicolumn{2}{|r|}{$I_{1}(\mathrm{IW}: \mathrm{CPE}=1.0)$} & 2188 & 1505 & 35 \\
\hline \multicolumn{2}{|r|}{$\mathrm{I}_{2}(\mathrm{IW}: \mathrm{CPE}=0.8)$} & 2157 & 1456 & 29 \\
\hline \multicolumn{2}{|r|}{$\mathrm{I}_{3}(\mathrm{IW}: \mathrm{CPE}=0.6)$} & 2101 & 1312 & 23 \\
\hline \multicolumn{2}{|r|}{$\operatorname{SEm}( \pm)$} & 13 & 20 & 0.3 \\
\hline \multicolumn{2}{|r|}{ CD (at 5\%) } & 52 & 78 & 1.0 \\
\hline \multicolumn{2}{|r|}{$M_{0}$ (Control) } & 2038 & 1071 & 26 \\
\hline \multicolumn{2}{|c|}{$\mathbf{M}_{1}$ (Polythene mulch) } & 2257 & 1730 & 32 \\
\hline \multicolumn{2}{|c|}{$M_{2}$ (Paddy straw mulch) } & 2101 & 1345 & 28 \\
\hline \multicolumn{2}{|c|}{$M_{3}($ Geotextile mulch) } & 2198 & 1550 & 30 \\
\hline \multicolumn{2}{|r|}{$\operatorname{SEm}( \pm)$} & 14 & 16 & 0.3 \\
\hline \multicolumn{2}{|r|}{ CD (at 5\%) } & 41 & 46 & 0.8 \\
\hline \multicolumn{2}{|r|}{$\mathbf{I}_{1} \times \mathbf{M}_{0}$} & 2098 & 1150 & 33 \\
\hline \multicolumn{2}{|r|}{$\mathbf{I}_{1} \times \mathbf{M}_{1}$} & 2270 & 1795 & 37 \\
\hline \multicolumn{2}{|r|}{$\mathbf{I}_{1} \times \mathbf{M}_{2}$} & 2145 & 1410 & 34 \\
\hline \multicolumn{2}{|r|}{$\mathbf{I}_{1} \times \mathbf{M}_{3}$} & 2238 & 1668 & 35 \\
\hline \multicolumn{2}{|r|}{$\mathbf{I}_{2} \times \mathbf{M}_{0}$} & 2045 & 1046 & 26 \\
\hline \multicolumn{2}{|r|}{$\mathbf{I}_{2} \times M_{1}$} & 2259 & 1791 & 33 \\
\hline \multicolumn{2}{|r|}{$\mathbf{I}_{2} \times \mathbf{M}_{2}$} & 2102 & 1354 & 28 \\
\hline \multicolumn{2}{|r|}{$\mathbf{I}_{2} \times \mathbf{M}_{3}$} & 2222 & 1629 & 32 \\
\hline \multicolumn{2}{|r|}{$\mathbf{I}_{3} \times \mathbf{M}_{0}$} & 1972 & 1019 & 18 \\
\hline \multicolumn{2}{|r|}{$\mathbf{I}_{3} \times \mathbf{M}_{1}$} & 2241 & 1605 & 27 \\
\hline \multicolumn{2}{|r|}{$\mathbf{I}_{3} \times \mathbf{M}_{2}$} & 2057 & 1272 & 23 \\
\hline \multicolumn{2}{|r|}{$\mathbf{I}_{3} \times \mathbf{M}_{3}$} & 2135 & 1352 & 22 \\
\hline & $\operatorname{SEm}( \pm)$ & 24 & 27 & 0.5 \\
\hline $\mathbf{I} \times \mathbf{M}$ & CD (at 5\%) & NS & 80 & 1.4 \\
\hline
\end{tabular}


Table.4 Pearson's correlation between (a) soil temperature and growth parameters, (b) soil temperature and yield attributes and (c) soil temperature and yield parameters

\begin{tabular}{|c|c|c|c|c|}
\hline Growth parameters & $\begin{array}{c}\text { ST }_{\mathbf{5 m}} \mathbf{6 0} \\
\text { DAS }\end{array}$ & & ST $_{\text {10 cm }}$ 60 DAS & \\
\hline Plant height 60 DAS & 0.454 & $* * *$ & \\
\hline Number of leaf plant ${ }^{-1}$ 60 DAS & 0.638 & $* * *$ & 0.344 & $* *$ \\
\hline Root length 60 DAS & 0.329 & $*$ & & \\
\hline Shoot length 60 DAS & 0.694 & $* * *$ & 0.392 & $*$ \\
\hline Shoot girth 60 DAS & 0.479 & $* * *$ & & \\
\hline
\end{tabular}

(a)

\begin{tabular}{|c|c|c|c|c|c|c|c|c|}
\hline $\begin{array}{c}\text { Yield } \\
\text { attributes }\end{array}$ & $\begin{array}{c}\mathrm{ST}_{5 \mathrm{~cm}} \\
60 \\
\text { DAS }\end{array}$ & & $\begin{array}{c}\text { Yield } \\
\text { attributes }\end{array}$ & $\begin{array}{l}\mathrm{ST}_{10 \mathrm{~cm}} \\
60 \text { DAS }\end{array}$ & & $\begin{array}{c}\text { Yield } \\
\text { attributes }\end{array}$ & $\begin{array}{l}S_{20} \mathrm{~cm} \\
60 \mathrm{DAS}\end{array}$ & \\
\hline Cob length & 0.693 & $* * *$ & Cob length & 0.567 & $* * *$ & Cob length & 0.459 & $* * *$ \\
\hline Cob weight & 0.482 & $* * *$ & Cob girth & 0.349 & $* *$ & Cob girth & 0.283 & $*$ \\
\hline Cob girth & 0.697 & $* * *$ & Corn length & 0.383 & $* *$ & & & \\
\hline Corn length & 0.524 & $* * *$ & & & & & & \\
\hline Corn weight & 0.500 & $* * *$ & & & & & & \\
\hline Corn girth & 0.454 & $* * *$ & & & & & & \\
\hline
\end{tabular}

(b)

\begin{tabular}{|c|c|c|c|c|c|c|}
\hline Yield parameters & $\begin{array}{c}\mathrm{ST}_{5 \mathrm{~cm}} 60 \\
\text { DAS }\end{array}$ & & $\begin{array}{c}\mathrm{ST}_{10 \mathrm{~cm}} 60 \\
\text { DAS }\end{array}$ & & $\begin{array}{c}\mathrm{ST}_{20 \mathrm{~cm}} 60 \\
\text { DAS }\end{array}$ & \\
\hline Cob yield & 0.607 & $* * *$ & 0.535 & $* * *$ & 0.288 & $*$ \\
\hline Corn yield & 0.774 & $* * *$ & 0.584 & $* * *$ & 0.394 & $* *$ \\
\hline Green fodder yield & 0.387 & $* *$ & & & & \\
\hline
\end{tabular}

(c)

Sample size $(\mathrm{N})=36$, *Significant at $5 \%$ level, $* *$ Significant at $1 \%$ level, $* * *$ Significant at $0.01 \%$ level. ST $=$ soil temperature $\left({ }^{\circ} \mathrm{C}\right), \mathrm{DAS}=$ days after sowing 
Fig.1 Soil temperature at 5,10 and $20 \mathrm{~cm}$ depths under different irrigation and mulch
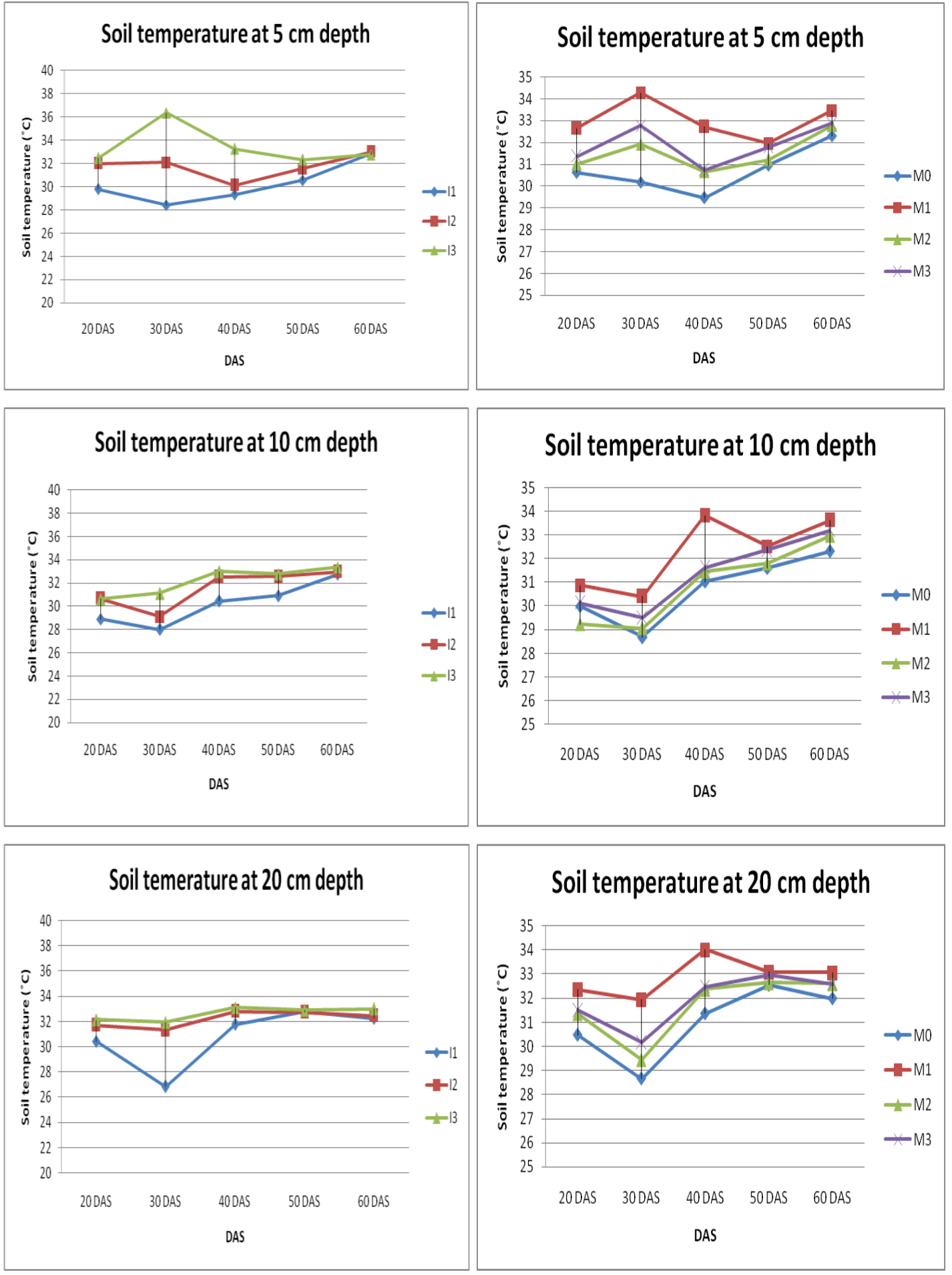
Fig.2 Effect of irrigation and mulch on yield attributes of summer baby corn (pooled)
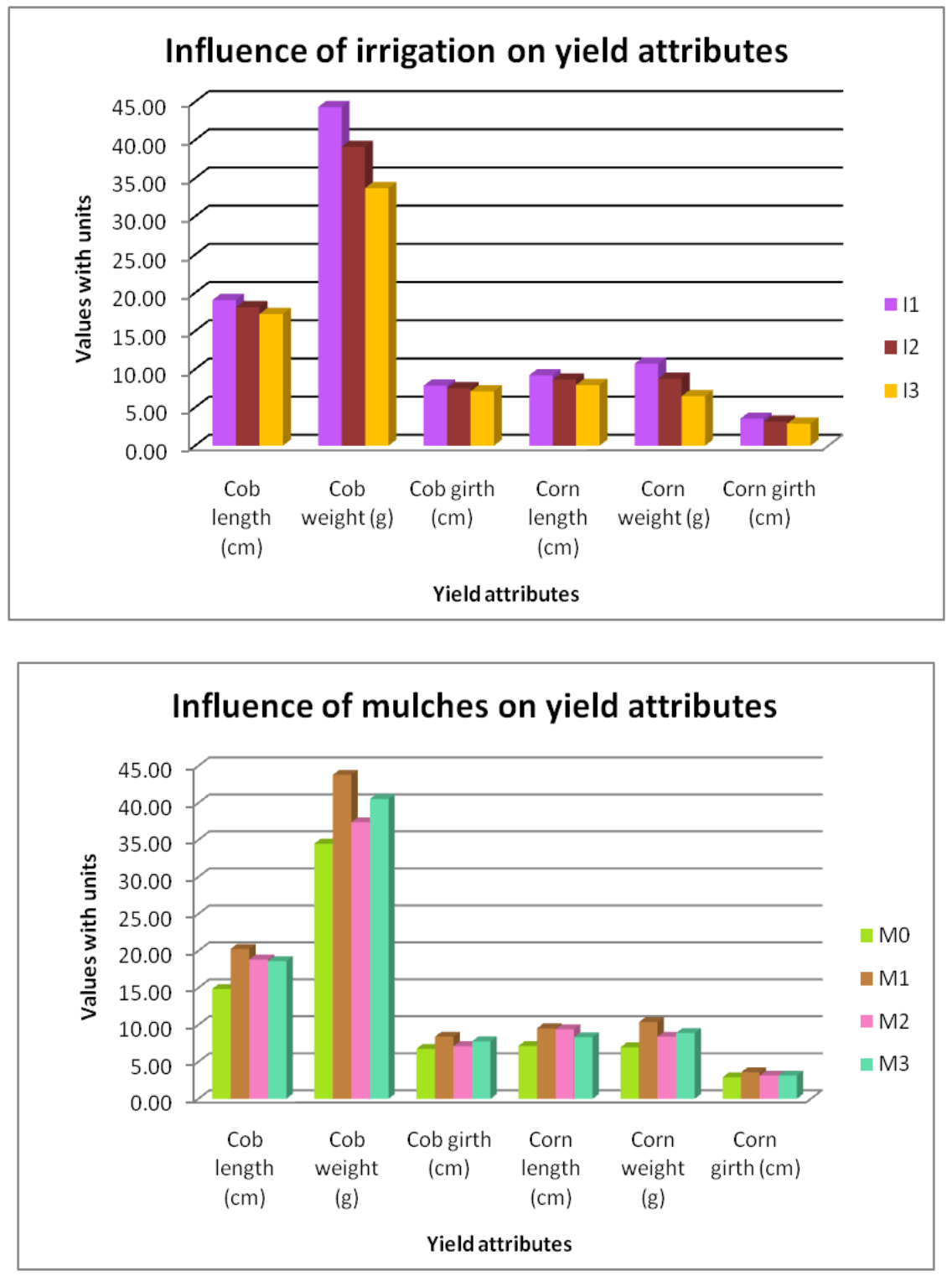

Maximum shoot girth was recorded by IW: CPE $1.0(7.44 \mathrm{~cm})$ and polythene mulch $(7.41$ $\mathrm{cm})$. Interaction effect $(\mathrm{I} \times \mathrm{M})$ for these parameters found to be statistically significant during all observational phases (Table 2).

\section{Influence of irrigation and mulch on yield attributes}

IW: CPE $1.0\left(\mathrm{I}_{1}\right)$ recorded significantly the highest cob length $(19.08 \mathrm{~cm})$, while IW: CPE
$0.6 \quad\left(\mathrm{I}_{3}\right)$ recorded significantly lower cob length $(17.23 \mathrm{~cm})$. Application of irrigation at IW: CPE 1.0 gave higher weight $(44.33 \mathrm{~g})$ and girth $(7.86 \mathrm{~cm})$ of baby corn with husk, though effect of irrigation was not significant in cob girth of baby corn. Significantly higher length $(9.22 \mathrm{~cm})$, weight $(10.75 \mathrm{~g})$ and girth $(3.54 \mathrm{~cm})$ of dehusked baby corn was recorded by IW: CPE $1.0\left(\mathrm{I}_{1}\right)$ followed by IW: CPE $0.8\left(\mathrm{I}_{2}\right)$ and IW: CPE $0.6\left(\mathrm{I}_{3}\right)$ (Figure 2). The increase in the length, weight and girth of 
cobs (husked and dehusked) under higher level of irrigation schedules might be due to constant soil moisture availability up to later growth stage of plant. These findings are in corroboration with the results of Rajendran and Singh (1999) and Oktem and Oktem (2009). Maximum cob length $(20.28 \mathrm{~cm}, 9.54$ $\mathrm{cm})$; cob weight $(43.80 \mathrm{~g}, 10.38 \mathrm{~g})$ and cob girth $(8.40 \mathrm{~cm}$ and $3.59 \mathrm{~cm})$ with and without husk respectively was recorded by applying polythene mulch $\left(\mathrm{M}_{1}\right)$ and lowest by no mulch $\left(\mathrm{M}_{0}\right)$ treatments. This might be due to regular supply of all nutrients at progressive growth stage of crop under mulch allowed satisfactory metabolic process in plant. Similar findings were also reported by Gossavi (2006).

Influence of irrigation and mulch on Cob yield (with and without husk) and green fodder yield

From the pooled data furnished in Table: 3 , it is clear that highest cob yield of $2188 \mathrm{~kg} \mathrm{ha}^{-1}$, corn yield or dehusked cob yield of $1505 \mathrm{~kg}$ $\mathrm{ha}^{-1}$ and green fodder yield of $35 \mathrm{t} \mathrm{ha}^{-1}$ was achieved by applying irrigation at IW: CPE 1 $\left(\mathrm{I}_{1}\right)$, though cob yield and corn yield from IW: CPE $0.8\left(\mathrm{I}_{2}\right)$ were statistically at par with that of $\mathrm{I}_{1}$. Higher yield produced might be due to higher number of functional leaves, higher root-shoot length, could have been resulted into higher synthesis of assimilate and thereby higher yield (Shivakumar et al., 2011). Application of mulches over soil surface played vital role in yield of baby corn, reported maximum cob yield with and without husk (2257, $1730 \mathrm{~kg} \mathrm{ha}{ }^{-1}$ respectively), and highest green fodder yield (32 $\mathrm{t} \mathrm{ha}^{-1}$ ) by polythene mulch $\left(\mathrm{M}_{1}\right)$ and lowest yield from control plots $\left(\mathrm{M}_{0}\right)$. This might be due to soil moisture non stress situation throughout growth period of crop resulted in more growth and yield attributes in mulching treatment which was reflected higher yield ( Bhatt et al., 2004).
Correlation of soil temperature affected by irrigation and mulch with different growth parameters, yield attributes and yield of baby corn

Soil temperature $\left({ }^{\circ} \mathrm{C}\right)$ at different depths had a very good positive correlation with different growth parameters, yield attributes and yield parameters (Table: 4; a, b and c).Very strong association was observed with soil temperature $(5 \mathrm{~cm}$ depth) and plant height $(\mathrm{r}=0.454)$, number of functional leaves plant $^{-1}$ $(r=0.638)$, and root length $(r=0.694)$ at the time of harvest. Significantly very high correlation was recorded with soil temperature at harvest $(5 \mathrm{~cm}$ depth) and cob length $(\mathrm{r}=0.693)$, cob weight $(\mathrm{r}=0.482)$, cob girth $(\mathrm{r}=0.697)$, corn length $(\mathrm{r}=0.524)$, corn weight $(\mathrm{r}=0.500)$ and corn girth $(\mathrm{r}=0.454)$; soil temperature at harvest $(10 \mathrm{~cm}$ depth and $20 \mathrm{~cm}$ depth) with cob length ( $\mathrm{r}=0.567,0.459$ respectively). Soil temperature at $5 \mathrm{~cm}$ and 10 $\mathrm{cm}$ depth during harvesting was strongly correlated with cob yield $(\mathrm{r}=0.607,0.535$ respectively), corn yield $(\mathrm{r}=0.774,0.584$ respectively).

From this study it can be concluded that with proper irrigation scheduling exact amount of water was applied according to the crop need and by applying different kind of mulches, soil moisture could be stored for longer time, thus preventing water loss which increased water use efficiency of crop. Thus providing suitable soil micro-environment by irrigation and mulches; crop growth, yield attributes and yield of summer baby corn at Gangetic West Bengal could be optimized.

\section{References}

Bhatt, Rajan., Khera, K.L. and Arora, Sanjay. (2004). Effect of tillage and mulching on the yield of corn in the sub montaneaus rainfed region of Punjab. Int. J. agric. and Bio, 6 (1): 126-128. 
Black C.A. (1965). "Methods of Soil Analysis: Part I Physical and mineralogical properties". American Society of Agronomy, Madison, Wisconsin, USA.

Dr. Vibha Dhawan (2017). Water and Agriculture in India Background paper for the South Asia expert panel during the Global Forum for Food and Agriculture (GFFA).

Gomez, K.A., and Gomez, A. (1984). Statistical Procedure for Agricultural Research, $2^{\text {nd }}$ edn. John Willy and Sons, New York, USA, 680 p.

Gosavi. (2006). Effect of mulches, fertilizer and levels of organic manure on the performance of rabi sweet corn (Zea mays saccharata). M.Sc. (Agri.) Thesis, Dr. Balasaheb Sawant Konkan Krishi Vidyapeeth, Dapoli, Dist. Ratnagiri (M.S.).

Hussaini, M. A., Ogunlela, V. B., Ramalan, A.A. and Falaki, A. M. (2001).Growth and development of maize (Zea mays L.) in response to different levels of nitrogen, phosphorus and irrigation. Crop Res, 22(2): 141-149.

Muragan, M., Gopinath, G., and Krishna Manohar, R. (2003). Effect of mulching on soil moisture and soil temperature in crossandra cv. SOUNDHARYA,
Mysore J. Agric. Sci, 37: 306-309.

Oktem, A. and Oktem, A. G. (2009). Yield characteristics of sweet corn under deficit irrigation in Southeastern Turkey. Philipp. Agric. Scientist, 92(3): 332-337.

Pandey, A. K., Prakash, V., Mani, V. P. and Singh, R. D., (2000). Effect of rate of nitrogen and time of application on yield and economics of baby corn (Zea mays L.). Indian Journal of Agronomy, 45(2): 338-343.

Rajendran, K. and Sundersingh, S. D. (1999). Effect of irrigation regimes and nitrogen levels on yield, water requirement, water use efficiency and quality of baby corn (Zea mays L.). Agric. Sci. Digest Karnal, 19(3): 159-161.

Shivakumar, H. K., Ramchanrappa, B. K., Nanjappa, H.V. and Mudalagiriyappa (2011). Effect of phenophase based irrigation schedules on growth, yield and quality of baby corn (Zea mays L.). Agric. Sci., 2(3): 267-272.

Uwah D.F. and Iwo, G.A. (2011). Effectiveness of organic mulch on the productivity of maize (Zea mays L.) and weed growth. J. Animal \& Pl. Sci, 21(3): 525-530.

\section{How to cite this article:}

Trisha Manna, G. Saha, M.K. Nanda, D. Dutta and Saha, A. 2019. Influence of Modified Soil Environment on Growth and Yield of Summer Baby Corn (Zea mays L.) as Affected by Irrigation and Mulch in West Bengal, India. Int.J.Curr.Microbiol.App.Sci. 8(01): 121-132. doi: https://doi.org/10.20546/ijcmas.2019.801.015 